\title{
The missing Other: a review of Linklater's Violence and Civilization in the Western States-System
}

\author{
L. H. M. Ling*
}

The New School

\begin{abstract}
As Andrew Linklater has shown, Europeans have decreased their tolerance for, or endorsement of, violence over the centuries. Various international and domestic conventions demonstrate the point. This accomplishment rightfully deserves celebration. But herein lies the rub. While Linklater recognises the role of imperialism and colonialism in perpetrating global violence, he does not grant equal opportunity to the Rest in contributing to the world's new moral heights. Linklater assumes, for instance, that Las Casas never talked with indigenes to realise that they, too, warrant recognition as human beings; Catholic piety alone sufficed. The West thus towers in singular triumph, embedding International Relations (IR) in what I call Hypermasculine Eurocentric Whiteness (HEW). Still, the Other retains a sense of its Self. An effervescent spirit of play enables resilience and creativity to co-produce our world-of-worlds. Come out and play!, I urge. It's time to shed IR's 'tragedy' for the sparkle within.
\end{abstract}

\section{Keywords}

Hypermasculinity; Eurocentrism; Whiteness; Play

\section{Introduction}

Possessing a curious mind, I could not resist reviewing a book with words like 'violence' and 'civilization' and the 'Western states-system' in its title. But as a postcolonial scholar - and a feminist one at that - I could not help but feel a certain amount of heat rising while progressing through the manuscript, despite the considerable light it sheds. Let me state up front: reviewing Andrew Linklater returns a familiar scenario to subalterns. Linklater may duly criticise imperialism and colonialism as a source of globalised violence in the Western states-system but he still disappears the Other. It remains unseen, unheard and unfelt, both analytically and empirically. This sleight of mind contributes to a larger history of epistemic violence in International Relations (IR): that is, Hypermasculine Eurocentric Whiteness (HEW). (More on this below.) And such erasure incurs predictable, political violence: that is, revenge terrorism from the outraged Other and fascist (alt-right) threats from the injured Self. Not coincidental is the fact that most terrorists against the West come from the West. ${ }^{1}$ Linklater thus rehearses HEW's fixation with itSelf at the expense of all Others even while claiming moral victory on behalf of all humankind.

* Correspondence to: L. H. M. Ling, Julien J. Studley Graduate Program in International Affairs, The New School, 72 Fifth Avenue, New York, NY, 10011, US. Author's email: LingL@newschool.edu

${ }^{1}$ Ebby Abramson and L. H. M. Ling, 'Islamic Radicalization: What, How, Why?', paper to be delivered at a panel, 'Dimensions of Power in Global Politics', at the $11^{\text {th }}$ Pan-European Conference on International Relations, European International Studies Association (EISA) in cooperation with the Institut Barcelona d'Estudis Internacionals, Barcelona, 13-16 September 2017. 
Given the gravity of these concerns, I decide to write this review as a personal journey. It allows me to speak honestly and from the perspective of a caring friend. After all, the West lives in me just as I live in the West. But - and this is the point - my experiences as a subaltern woman necessarily lead to different interpretations and understandings of the West. And these deserve an open airing. ${ }^{2}$ Too often, Westphalian IR marginalises, truncates, or dismisses difference under calls for 'rigour' or 'parsimony'. Instead of abiding by these predetermined parameters of discourse that invariably shape its outcome, ${ }^{3}$ I resort to the art of play. ${ }^{4}$ I hope this journal-like review begins a much-needed conversation in IR.

A second technique shapes this review. Given the book's 500+ pages, I draw on one, representative chapter - 'Chapter 6: Cruelty and Compassion in the Age of Empire' - to illustrate my argument while keeping it succinct.

Now, onto the review!

\section{Commendations}

Let me first commend the author. He has compiled an impressive array of knowledge in one tome, beginning with the Hellenic city states-system to the rise of Rome to the mercantilist European states and their overseas empires to Europe's Enlightenment to contemporary, modern times. (And I've skipped over several centuries in between!) Linklater also advances a certain understanding of IR that combines a sociology of civilisational processes, pioneered by Norbert Elias, with the expansion of international society most articulated by and identified with the English School. Linklater asks: how did modern Europeans become more civilised than their medieval forbearers? And by more civilised, he means less violent and/or less tolerant of violence. The Universal Declaration of Human Rights and Responsibility to Protect (R2P) shine as two major exemplars.

Linklater thus gives new meaning and significance to the concept of 'international society'. More than an agglomeration of individual states with a common regime of structures and functions (despite, the English School insists, an inherent anarchy in world politics), the notion of an 'international society' now takes on an ethical badge of honour. It compels us to attain greater heights of morality - that is, civilisation - as a way of being in the world.

So far, so good, I mutter to myself. Who could disagree? But an eyebrow begins to arch as I continue reading.

2 '[W]hen we speak of hurt feelings and intentionality, whose feelings are we systematically valuing more than others' in our strategic reluctance? How does this play into the colonial status quo and the expendability of certain experiences and lives?'. See Olivia Umurerwa Rutazibwa, 'From the everyday to IR: In defence of the strategic use of the R-word', Postcolonial Studies, 19:2 (2016), p. 195.

${ }^{3}$ See, for example, Kimberly Hutchings, 'Dialogue between whom? The role of the West/non-West distinction in promoting global dialogue in IR', Millennium: Journal of International Studies, 39:3 (2011), pp. 1-9, Kimberly Hutchings, 'Speaking and hearing: Habermasian discourse ethics, feminism and International Relations', Review of International Studies, 31 (2005), pp. 155-65.

${ }^{4}$ For an understanding of the 'artistic turn' in IR, see Roland Bleiker, Aesthetics and World Politics (London: Palgrave Macmillan, 2009). On play and IR, see Elina Penttinen, Joy and International Relations: A New Methodology (War, Politics, Experience) (London: Routledge, 2013) and Saara Särmä, 'Junk Feminism and Nuclear Wannabes - Collaging Parodies of Iran and North Korea' (PhD thesis, Department of International Relations, Tampere University, 2014), available at: \{http://urn.f/URN:ISBN:978-951-44-9535-9\} accessed 9 March 2017. 


\section{Westphalia-Europe-Empire}

'Civilized self-images' emerge in the West, Linklater writes, from a triangulation of modernity: that is, Westphalia-Europe-Empire. He specifies it as 'state formation', a 'European international society', and the 'rise of overseas empires' for Europe. Four 'major shifts' followed. Changes in the 'balances of power' between 'competing social dynamics' produced: ${ }^{5}$

1. 'moral sensitivities ... as people became bound together in more complex societies';

2. 'ethical restraints on the use of force [given] the capacity to cause greater harm to more and more people over ever larger distances';

3. 'the fear of retaliation or ..."conscience"; and,

4. a sense of 'responsibilities for citizens ... [that] uphold[s] the rights of individual persons to be spared unnecessary suffering' ${ }^{6}$

$H m$, methinks.

Violence begets civilisation, Linklater argues, and it does so autonomously. Like Karl Polanyi's 'double movement', whereby society seeks to recuperate from abuses in the economy to maintain equilibrium in both, ${ }^{7}$ so Linklater finds that systemic inequities, cruelties, enslavements, and killings induce ethical restraints within the same system. The West thus transforms itself by itself for itself. No one or nothing else is involved or needed.

Sounds familiar. Carol Cohn tells a similar tale regarding sex and death among defence intellectuals. ${ }^{8}$ They, too, fancied themselves capable of asexual reproduction. They talked about killing on a massive scale while, at the same time, fathering new weapons, new strategies, new worlds. They had no need for any kind of a partner - or remorse.

Linklater adds:

European feelings of cultural superiority and repugnance towards various non-European social practices were not manifestations of a completed civilizing process: they were critical elements in the formation of 'civilized' self- images. ${ }^{9}$

Now the heat begins to burn. Five questions immediately fire up: where, who, what, why, and how?

\section{Five questions}

\section{Where? Only the West}

Where, I ask, is the role and impact of Others outside Westphalia-Europe-Empire? How could they figure so intimately in this triangulation of modernity, through centuries of colonialism and

${ }^{5}$ Andrew Linklater, Violence and Civilization in the Western States-System: Part Two of the Problem of Harm in World Politics (Cambridge: Cambridge University Press, 2016), p. 46.

${ }^{6}$ Ibid.

${ }^{7}$ Karl Polanyi, The Great Transformation: The Political and Economic Origins of Our Time (Boston: Beacon Press, 1944).

${ }^{8}$ Carol Cohn, 'Sex and death in the world of rational defense intellectuals', Signs: Journal of Women in Culture and Society, 12:4 (1987), pp. 687-718.

${ }^{9}$ Ibid., p. 226. 
imperialism, yet fail to have a presence, not to mention voice, in the outcome? Furthermore, evidence abounds of cross-civilisational world-making. ${ }^{10}$ These demonstrate that dialogues between Self and Other, West and Rest co-produced 'international society'. A hundred years before Westphalia, for example, a Jesuit priest named Matteo Ricci sought to Christianise Ming China by Confucianising Christianity. ${ }^{11}$ Ricci often wrote about how his articulations of faith and compassion, knowledge and enlightenment came through discourses with local leading lights. ${ }^{12}$ These include 'a long and acerbic debate with Abbot Xuelang Hong'en (d. 1607), the leading Buddhist cleric in Nanjing, whose erudition and personality had earned him an excellent reputation among the literati'. ${ }^{13}$

Where Others show up in Linklater's account, they impede Western progress. The colonised, Linklater claims, did not put up enough of a fight against European invaders, thereby enabling a moral laziness:

The 'civilizing process' would have unfolded in very different ways if Europeans had constituted the whole of humanity and if they had not entered into relations with other societies where, because of huge inequalities of power, there was little incentive or compulsion to observe the basic principles of reciprocity. The absence of such constraints on European societies is one reason why condescending or derogatory representations of outsiders have had a wholly unprecedented impact in the modern period. ${ }^{14}$

Somerset Maugham immediately comes to mind. ${ }^{15}$ This British raconteur and novelist extraordinaire recounts European colonisers on the edges of empire who committed all sorts of moral misconduct - murder, incest, rape - because, essentially, they were bored out of their minds. It had nothing to do with their inability to see and treat Others as worthy of social interaction and, by extension, learning.

\section{Who? White sovereigns}

Who are we talking about, really? Clearly, Linklater focuses on the West given his inquiry about morality in the Western states-system. But he privileges the sovereign patriarchs - from kings to philosophers to ordinary burghers - that feature most prominently in it. ${ }^{16}$ For example, Linklater commends Western kings for their remarkable ethical considerations despite the violence their national-royal households had perpetrated against Others in their name: 'It has been said that the court of Charles $\mathrm{V}$ was the first in European history to suspend imperial conquest while theologians debated its ethical foundations'.

${ }^{10}$ See, for example, Paul Gilroy, The Black Atlantic (Cambridge: Harvard University Press, 1995); John M. Hobson, The Eastern Origins of Western Civilisation (Cambridge: Cambridge University Press, 2004); and Takashi Shogimen and Cary J. Nederman (eds), Western Political Thought in Dialogue with Asia (Lanham, MD: Lexington Books, 2009).

${ }^{11}$ R. Po-chia Hsia, Matteo Ricci \& the Catholic Mission to China: A Short History with Documents (Indianapolis/ Cambridge: Hackett Publishing Company, Inc., 2016).

12 Ricci compiled these discourses into two main books, Tianzhu shiyi [True Meaning of the Lord of Heaven] and Jiren shipian [Ten Discourses of the Man of Paradox], Ibid., pp. 31-3.

13 Ibid., p. 29.

14 Ibid., p. 232.

${ }^{15}$ W. Somerset Maugham, Collected Short Stories, Volumes 1 and 2 (New York: Penguin Classics, 1992).

${ }^{16}$ See, for example, Genevieve Lloyd, The Man of Reason: 'Male' and 'Female' in Western Philosophy (2nd edn, London: Routledge, 1995). 
How white of them. ${ }^{17}$ I cannot help this slip into a contemporary colloquial expression. It's a person-of-color thing. Still, it's indicative. ${ }^{18}$

As usual, the Western Self remains immune to Others. Linklater attributes the West's enlightened restraint to internal institutional and discursive struggles:

An alternative interpretation is that an unanticipated major advance of human interconnectedness led to new power struggles, to complex discussions about the appropriate powers of different authorities, and to related ethical debates about the rights of colonial subjects. ${ }^{19}$

I sit back in my chair and take a calming sip of tea. I forge on.

\section{What? 'The horror, the horror!'}

To be fair, Linklater recognises the role of Western imperialism and colonialism in globalising violence. He notes:

Direct parallels were drawn between conceptions of savages who were under the control of 'immediate desire, without discipline, without constraint, without real morality', and the insane that were similarly beyond the reach of 'civilization'. ${ }^{20}$

In a footnote, Linklater details one case:

Changing attitudes to the slave trade were heightened by public responses to the legal case involving the slave ship, the Zong, whose crew in 1783 threw more than one hundred and thirty sick slaves overboard allegedly to conserve water but, in reality, to prevent the spread of disease, and to protect the monetary value of the remaining human cargo. The cost of the lost slaves was to be recovered through an insurance claim. The legal representative maintained that the action was entirely legitimate because 'the Blacks were property', the case of slaves being no different from casting horses overboard. ${ }^{21}$

Here, Linklater gives Others a rare nod - but that's it. He notes how 'slave testimonials by Cugoano and Equiano in Britain, and by Frederick Douglass, Nat Turner and others in the United States ${ }^{22}$ helped to turn the ethical tide against slavery. We know nothing, however, of what

${ }^{17}$ This expression derives from the saying, 'mighty white of you'. According to the Urban Dictionary, this phrase was '[o]riginally used under colonialism and before civil rights [to] expres[s] appreciation for honorable or gracious behavior, under the assumption that white people were inherently more virtuous. Today, it is generally used sarcastically in reference to underwhelming acts of generosity.' Available at: \{http://www. urbandictionary.com/define.php?term $=$ mighty $\% 20$ white $\% 20$ of $\% 20$ you accessed 4 March 2017. I would put it more directly. Here, acts of 'whiteness' refer to self-congratulatory instances of patronage that masquerade as benevolence. I thank Patricia J. Robertson for this articulation.

${ }^{18}$ Linklater's reference to 'complex responsibility' (p. 255) and 'imperial feminism' or 'white woman's burden' (p. 254) demonstrates the point. These notions focus only on white society's reactions to the cruelties of slavery, especially against women. We know nothing of what the slaves themselves felt, thought, did or said. Only focusing on white women's experiences with slavery at the expense of all Others amounts to another act of HEW but under the guise of so-called feminism. See Chandra Talpade Mohanty, 'Under Western eyes: Feminist scholarship and colonial discourses', boundary 2, 12:3 and 13:1 (1984), pp. 333-58.

${ }^{19}$ Linklater, Violence and Civilization, p. 244.

${ }^{20}$ Quoting Foucault, Ibid., p. 247.

${ }^{21}$ Ibid., p. 257.

${ }^{22}$ Ibid. 
these testimonials entailed nor how they influenced white society's thinking about ethics and morality at the time.

To amend the record, I insert a brief excerpt here:

if any man should buy another man without his own consent, and compel him to his service and slavery without any agreement of that man to serve him, the enslaver is a robber, and a defrauder of that man every day. Wherefore it is as much the duty of a man who is robbed in that manner to get out of the hands of his enslaver, as it is for any honest community of men to get out of the hands of rogues and villains. And however much is required of men to forgive one another their trespasses in one respect, it is also manifest, and what we are commanded, as noble, to resist evil in another, in order to prevent others doing evil, and to keep ourselves from harm. Therefore, if there was no way to deliver a man from slavery, but by enslaving his master, it would be lawful for him to do so if he was able, for this would be doing justice to himself, and be justice as the law requires, to chastise his master for enslaving of him wrongfully - Quobna Ottobah Cugoana (aka 'John Stuart', 1787). ${ }^{23}$

In effect, Linklater victimises Others twice. Like those who suffer rape and/or domestic abuse, the formerly colonised become victims only: first, as recipients of violence; secondly, erasure. ${ }^{24}$ Without any capacity for speech, thought or action, Others can only labour on as beasts of burden or objects of sex. And such non-personhood persists in the analytical imagination even when lived realities no longer apply. Righteous anger and revenge fantasies invariably flare and flame. Like countless women who couldn't take it anymore and killed their abusive husbands in their sleep, Osama bin Ladin justified al-Qaeda's attacks on New York and Washington as retribution. ${ }^{25}$ Linklater would have done well to learn from both precedents.

Instead, Linklater deftly shifts attention from the barbarity of slavery to capitalism. He cites a Spanish conquistador: 'Bernal Diaz del Castillo, one of Cortes' companions, probably captured the dominant outlook when he stated that 'we came here to serve God, and the king, and also to get rich'. ${ }^{26}$ Inhumane and venal though they were, says Linklater, these acts prompted the West to attain greater heights of self-awareness, civilisation, and 'conscience', in due time.

My postcolonial-feminist soul is now fully ablaze. I must open a window for air.

\section{Silenced voices, silenced histories}

I think of the slaves of Haiti who emancipated themselves at a time (1791-1804) when white society thought them incapable of human thought or emotion. The revolutionaries demanded equality in

${ }^{23}$ Quobna Ottobah Cugoano, Thoughts and Sentiments on the Evil and Wicked Traffic of the Slavery and Commerce of the Human Species, Humbly Submitted to the Inhabitants of Great Britain, in Henry Louis Gates, Jr and William L. Andrews (eds), Pioneers of the Black Atlantic: Five Slave Narratives from the Enlightenment, 1772-1815 (Washington, DC: Counterpoint, 1998), p. 134.

${ }^{24}$ Lisa Adler and L. H. M. Ling, 'From practice to theory: Toward a dissident-feminist reconstruction of nonviolence', Gandhi Marg: Journal of the Gandhi Peace Foundation, 16:4 (1995), pp. 462-80.

25 A. M. Agathangelou and L. H. M. Ling, 'Power, borders, security, wealth: Lessons of violence and desire from September 11', International Studies Quarterly, 48:3 (2004), pp. 517-38.

${ }^{26}$ Linklater, Violence and Civilization, p. 240. 
economic, social, and cultural terms, seeing each as necessary to human dignity. ${ }^{27}$ They also graciously forgave their former masters, recognising their right to live in this brave new world. ${ }^{28}$ Eurocentric history, however, buries this extraordinary act of Self by an enslaved Other as a 'rebellion' while crediting the citiyons of France and the settler-colonists of America with 'revolution'.

I think, also, of Sojourner Truth. In her speech, 'Ain't I a Woman?', delivered at the 1851 Women's Rights Convention in Akron, Ohio, she reminds us of what it means to be not just a woman but also a human being:

That man over there says that women need to be helped into carriages and lifted over ditches, and to have the best place everywhere. Nobody ever helps me into carriages, or over mudpuddles, or gives me any best place! And ain't I a woman? Look at me! Look at my arm! I could have ploughed and planted, and gathered into barns, and no man could head me! And ain't I a woman? I could work as much and eat as much as a man - when I could get it - and bear the lash as well! And ain't I a woman? I have borne thirteen children, and seen them most all sold off to slavery, and when I cried out with my mother's grief, none but Jesus heard me! And ain't I a woman? ${ }^{29}$

Listen to me and hear my story, she urges. In acknowledging my humanity, she suggests, you regain yours even if you had abused me in the past. And on this basis of interpersonal, intersubjective resonance, I add, we may arrive at a more just understanding of morality. ${ }^{30}$

\section{Why? Unicornic West}

Linklater, however, fashions morality and the West (the two become coterminous) into a fantastic unicorn: ${ }^{31}$ tremblingly white, rare, and unique yet also strong, everlasting and self-generative. As noted with Cohn's tale about defence intellectuals, the unicornic West self-produces; at the same time, it acts as a patriarchal god by reproducing mini-Wests through the cultural-civilisational womb of the non-Western Other. ${ }^{32}$ In this scenario, Others cannot partner in the making of

${ }^{27}$ For alternative understandings of slavery, the Haitian Revolution and its impact on IR theory, if not 'international society', see Robbie Shilliam, 'What the Haitian Revolution might tell us about development, security, and the politics of race', Comparative Studies in Society and History, 50:3 (2008), pp. 778-808 and Robbie Shilliam, “'Open the gates mek we repatriate”: Caribbean slavery, constructivism and hermeneutic tensions', International Theory, 6:2 (2014), pp. 349-72; Siba N. Grovogui, 'Otherwise human: the institutes and institutions of rights', available at: $\{$ https://sibagrovogui.com/current-projects/otherwise-human-the-institutesand-institutions-of-rights/\} accessed 3 March 2017; and Siba N. Grovogui, 'Deferring difference: a postcolonial critique of the "race problem" in moral thought', in Sanjay Seth (ed.), Postcolonial Theory and International Relations: A Critical Introduction (London: Routledge 2013), pp. 106-23.

${ }^{28}$ As president, Nelson Mandela extended the same kind of forgiveness to South Africa's white population when apartheid ended in the 1990 s, two centuries after the Haitian revolution.

29 Sojourner Truth, 'Ain't I a Woman?', Women's Convention, Akron, Ohio, 28-9 May 1851, available at: \{http://schools.nyc.gov/NR/rdonlyres/E151FA9D-6017-4556-981F-CD076D731A72/0/SecondaryTextGuide AnswerKeyAintWoman.pdf\}.

${ }^{30}$ For more on the notion of resonance in IR, see L. H. M. Ling, The Dao of World Politics: Towards a PostWestphalian, Worldist International Relations (London: Routledge, 2014).

${ }^{31}$ For how Western/Westphalian IR has done so historically and intellectually, see John M. Hobson, The Eurocentric Conception of World Politics: Western International Relations Theory, 1760-2010 (Cambridge: Cambridge University Press, 2012) and Robert Vitalis, White World Order, Black Power Politics: The Birth of American International Relations (Ithaca: Cornell University Press, 2015).

${ }^{32}$ Edward W. Said, Culture and Imperialism (New York: Vintage Books, 1994). 
our world-of-worlds. ${ }^{33}$ They do not - cannot - inspire or command. Others can only serve as dispensable pawns in this inevitable march towards European modernity.

So what?, a critical reader could retort. What does it matter if, ultimately, we have a more enlightened international society?

Enter the ghost of J. Robert Oppenheimer. It offers insight into what Linklater's analysis means for you, me, and the world.

\section{The ghost of J. Robert Oppenheimer}

J. Robert Oppenheimer could serve as a poster child for Linklater's West and its capacity for autonomous morality. As director of the Manhattan Project, Oppenheimer oversaw the design and execution of the world's first atom bomb. Yet throughout his life, Oppenheimer renounced weapons of mass destruction (WMDs). Oppenheimer personifies, accordingly, the 'four shifts' Linklater identified in the West's ethical landscape: moral sensitivities in face of complex interconnectedness, ethical restraints against the use of unprecedented force, fear of retaliation or 'conscience', and a sense of global responsibilities. But Oppenheimer's personal history also shows why self-rectification ultimately fails.

\section{Oppenheimer and the bomb}

'I am become death, the destroyer of worlds. ${ }^{34}$ Oppenheimer uttered these words upon seeing the atom bomb's first detonation in the desert of Los Alamos, New Mexico, in July 1945. These words come from Lord Krishna in the Bhagavad Gita. He reveals himself as a god of gods to Prince Arjuna, who suffers from a paralysing guilt: he cannot come to terms with going to war with members of his own family. 'How can I kill my kin?', Arjuna laments. Do not worry about whom you will kill, Krishna counsels, for that is my domain. ${ }^{35}$ Nor expect rewards for your labour. Just be the best warrior you were born to be. That is your dharma (duty). Arjuna is convinced and takes up his bow and arrow (his archery resounds throughout the land). Arjuna wins the war but the victory rings hollow. After 18 days of bloody battle, hardly anyone from either side survives to rule. Such is the tragedy of the Mahabharata. Such is, also, the tragedy of Robert Oppenheimer.

Science, Oppenheimer believed, was his dharma. Massive destruction would result from the bomb but life and death were beyond Oppenheimer's moral ken. These matters belonged to the realm of the gods. Oppenheimer understood faith to mean a kind of spiritual purity and humility that sanctions an absence of moral judgment. The atom bomb could bring either world peace or world destruction: only time would tell. Meanwhile, action superseded the agony of reflection. 'I was more concerned then with doing what I should', Oppenheimer commented in 1966, 'than chattering about it'. ${ }^{36}$ But perhaps

${ }^{33}$ Onuf and Ling identify similar concepts: 'worlds within worlds' for the former, 'worlds of multiple worlds' for the latter. Nicholas Greenwood Onuf, Making Sense, Making Worlds: Constructivism in Social Theory and International Relations (London: Routledge, 2013) and Ling, The Dao of World Politics.

${ }^{34}$ James A. Hijiya, 'The Gita of J. Robert Oppenheimer', Proceedings of the American Philosophical Society, 144:2 (2000), p. 123.

${ }^{35}$ In effect, Krishna is saying to Arjuna: 'Act from dharma with detachment and God will take care of the rest.' Gavin Flood and Charles Martin, The Bhagavad Gita: A New Translation (New York: W. W. Norton \& Co., 2012), p. xv.

${ }^{36}$ Hijiya, 'The Gita of J. Robert Oppenheimer', p. 160. 
Oppenheimer, not to mention the world, would have benefited had he 'chatted' more, especially with the politicians and the generals. Together, they might have come up with a less radical act than atombombing a city on 'technical' merits. ${ }^{37}$

For the rest of his life, Oppenheimer wrestled with his conscience about the bomb. A pacifist and critic of the nuclear arms race, Oppenheimer referred to WMDs as 'devil's work': they demonstrate 'the inhumanity and evil of modern war'. ${ }^{38}$ Oppenheimer maintained that bombing Hiroshima and Nagasaki had been 'in error', scientists who had worked on the bomb had 'known sin', and he himself had 'blood on his hands'. ${ }^{39}$ Oppenheimer refuted Truman's contention that the bomb ended the war earlier than it would have, otherwise. Japan, Oppenheimer argued in 1959, was 'already essentially defeated'. ${ }^{40}$ He charged the US with unnecessary 'aggression', 'surprise', and 'terror' in dropping the bombs. ${ }^{41}$ Yet to his death, Oppenheimer maintained he had nothing to apologise for: he was merely doing his duty as a scientist. 'I never regretted, and do not regret now, having done my part of the job', he stated in $1965 .^{42}$ Despite a powerful intellect, Oppenheimer could not - would not - progress beyond this singular, insular position. He resisted entry into a larger consciousness. Neither did he allow that consciousness to penetrate his rationale.

Put differently, Oppenheimer refused intimacy with the Other. Even though Oppenheimer had studied the Gita since his twenties, calling it the 'most beautiful philosophical song existing in any known tongue, ${ }^{43}$ he never lived by it. That is, he never studied with a local guru or practised yoga ${ }^{44}$ on a daily basis or engaged in any way with the Gita on its own terms. This inability to accept the Other within the Self blocked Oppenheimer from relating to the Gita in its own philosophical context, thereby losing its dialogical import. In compartmentalising both himself and the Gita, Oppenheimer turned the notion of dharma into a technical expertise only. He never saw his dharma as a scientist in relation to all other possible dharmas: as a father, for instance, or even a philosopher. But, as Arti Dhand notes, '[d] harma enjoins care of all beings, irrespective of social standing or even species.... A person devoted to this dharma, therefore, is identified by his/her solicitude and kindness towards others. ${ }^{45}$

Michie Hattori attests to the consequences of Oppenheimer's insularity. She was a 15-year-old schoolgirl in Nagasaki on 9 August 1945:

What a terrible feeling! I could see nothing. My hands and face singed, intense pain gripped my body. I tried to walk a little and stumbled over a fallen tree. I lay there, not knowing for sure where I was or whether something else might happen to me.

${ }^{37}$ A 'firecracker over the desert', Oppenheimer explained in 1954, 'would not have intimidated the Japanese.' (Ibid., p. 144). One historian wonders: '[W] hat would have happened if Oppenheimer had firmly opposed the atomic bombardment of Japanese cities; would it have taken place, or not?' (Michel Rouzé quoted in Ibid., p. 165).

38 Ibid., pp. 127-8.

39 Ibid.

${ }^{40}$ Ibid., p. 127.

${ }^{41}$ Ibid.

42 Ibid., p. 141.

43 Oppenheimer quoted in Ibid., p. 130.

44 'Sanskrit scriptures can be understood intellectually, but some are sequences of vibrations with experiential "meanings" and can only be known through yogic practice.' Rajiv Malhotra, Being Different: An Indian Challenge to Western Universalism (New York: HarperCollins, 2011), p. 222.

${ }^{45}$ Arti Dhand, 'The dharma of ethics, the ethics of dharma: Quizzing the ideals of Hinduism', The Journal of Religious Ethics, 30:3 (2002), p. 354. 
Fires started all around us. Flames leaped from paper and wood scraps, some from collapsed structures. Thick smoke and dust filled the air. The fires gave the only real illumination. Even the noontime sunlight, filtering through the clouds, darkened. The word I kept hearing the girls say, jigoku, means hell. That's the closest I ever want to come to jigoku. ${ }^{46}$

Oppenheimer insisted that building the atom bomb was his destiny, his dharma. Such was his anguish. His greater sense of morality brought little peace of mind or heart.

Why do we keep doing this to ourselves?, I ponder. Why would anyone want Oppenheimer's tortured soul for their own?

\section{Another domestic analogy}

At this point, another kind of domestic analogy may apply. ${ }^{47}$ From Oppenheimer and the bomb, we move to marriage equality in the contemporary West. Both cases show a common reasoning at work, if we accept Linklater's premise. His argument about increasing morality in 'international society' resembles this claim by some: that is, Western culture achieved enlightenment about marriage equality without any input from the women's movement or the LGBTQA communities that demanded such changes in the first place. ${ }^{48}$ Marriage as a legal, economic and social institution, the argument goes, reformed itself due to internal, systemic revulsions against the types of violence that had abused and incarcerated a marital partner: for example, rapes, beatings, impoverishment, lack of rights, and so on. And since hetero-patriarchal men sit at the top of society and all its institutions, they deserve credit for making these reforms. Feminist and queer struggles over decades, if not generations, had nothing to do with them.

No one - I suspect not even hetero-patriarchal men - believes this claim. Yet it sticks, as demonstrated by the tome under review. Understanding how gives us further insight into why. And it takes two parts: local social power reinforced by a global infrastructure of HEW.

\section{V.i. How? Social power}

Those in charge, Linklater's analysis implies, should stay in charge. Whether it credits heteropatriarchal men in 'modernising' marriage or sovereign whites in building an 'international society' of increasing morality, this way of thinking assures us that self-rectification will follow - eventually. Even where decolonisation may have induced Others to 'reject' the West for 'indigenous' practices, Linklater writes, 'the "civilizing offensive" has continued in modified ways' given its utility for public policy. ${ }^{49}$ All that's required is time. The world just has to wait it out. Be patient.

46 'Michie Hattori: Eyewitness to the Nagasaki Atomic Bomb Blast', originally published in World War II magazine, Historynet.com (12 June 2012), available at: \{http://www.historynet.com/michie-hattori-eyewitnessto-the-nagasaki-atomic-bomb-blast.htm\}.

${ }^{47}$ A 'domestic analogy' in the English School typically refers to the law and order nature of states compared to the anarchic, murderous State of Nature that supposedly characterises world politics. Hidemi Suganami, 'The English School in a nutshell', Ritsumeikan Annual Review of International Studies, 9 (2010), pp. 15-28.

48 Moreover, many within the LGBTQA community still debate the merits of marriage equality, given its role as a mainstay in a capitalist global political economy. See Dean Spade and Craig Willise, 'Marriage will never set us free', Organizing Upgrade (6 September 2013), available at: \{http://www.organizingupgrade.com/index.php/ modules-menu/beyond-capitalism/item/1002-marriage-will-never-set-us-free\} accessed 7 March 2017. I thank Sara Shroff for this reference.

${ }^{49}$ Linklater, Violence and Civilization, p. 229. 
Right, I grimace. That's what all hegemons say. After the Second World War, many former colonisers recast their former colonies into 'protectorates' or 'territories' in order to 'prepare' them for self-governance. Accordingly, former colonisers often said to their former colonial subjects: 'just be patient, you'll be ready for self-rule soon - when we say'. In the twenty-first century, the 'liberal world order' is resurrecting a new version of this old chestnut. ${ }^{50}$ Feminists, too, critique this concept of the 'duty to yield' - that is, for women to wait in queue, to be true to their nature, to be patient. ${ }^{51}$ Never mind the Other, I say to myself, what does this mean for the Self?

Such analysis violates the Self as much as Others. In erasing Others, the West also erases itself, perhaps more so, since the violence is Self-inflicted. The Western Self needs Others to be the West; otherwise, by Linklater's own logic, how could the West morally develop without a target of violence? And such violence covers the spectrum from the physical to the cultural to the epistemic. 'Epistemicide' thus afflicts not only the Global South. ${ }^{52}$ Five centuries of colonialism and imperialism have gravely damaged the Global North as well. ${ }^{53}$ In this way, violence remains in IR, notwithstanding ceremonious declarations of rights, responsibilities, and so on. As a body of knowledge, Western IR crouches darkly inside, crippled and hurting, unable to play with Others outside.

No mere conjecture, this way of thinking reflects a venerable pedigree. In New Atlantis (1627), Sir Francis Bacon presents his ideal nation, Bensalem. It routinely scours the world for knowledge and skills, thereby keeping its people wealthy, healthy, and wise. Yet Bacon describes Bensalem in these terms:

You shall understand that there is not under the heavens so chaste a nation as this of Bensalem; nor so free from all pollution or foulness. It is the virgin of the world...For there is nothing amongst mortal men more fair and admirable, than the chaste minds of this people. ${ }^{54}$

But how is this possible? How could Bensalem retain a 'chastity' in mind and body while absorbing knowledge and skills from Others? Bacon offers the only possible answer: utilitarianism. ${ }^{55}$ Only a utilitarian could consume knowledge without being 'polluted' by that knowledge. Utility, Bacon suggests paradoxically, bears no norms, values or visions even though it does so precisely. Like the conquistadores of a century before, utilitarianism can combine God and King with Profits. For this reason, it can deliver expedience and a virginal morality.

As evidenced by Linklater's take on 'international society', Westphalian IR accepts this rendition of knowledge and morality. Indeed, it passes as normal. To understand how this ruse could

50 James Mayall and Ricardo Soares de Oliveira (eds), The New Protectorates: International Tutelage and the Making of Liberal States (New York: Columbia University Press, 2011).

${ }^{51}$ Hege Skjeie, “"Gender equality”: On travel metaphors and duties to yield', in Sirkku K. Hellsten, Anne Maria Holli, and Krassimira Daskalova (eds), Women's Citizenship and Political Rights (Palgrave Macmillan, 2006). I thank Shirin Rai for this reference.

52 Boaventura de Sousa Santos, Epistemologies of the South: Justice Against Epistemicide (Boulder, CO: Paradigm Publishers, 2014).

${ }^{53}$ For the reciprocal impact of colonialism and imperialism on the West, see Ashis Nandy, The Intimate Enemy: The Psychology of Colonialism (New Delhi: Oxford University Press, 1988) and L. H. M. Ling, Postcolonial International Relations: Conquest and Desire between Asia and the West (London: Palgrave Macmillan, 2002).

54 \{http://www.fcsh.unl.pt/docentes/rmonteiro/pdf/The_New_Atlantis.pdf\}.

55 Here, Bacon's utopic vision of Bensalem recalls Qing China's initial response to the challenge of the West: 'Chinese knowledge as essence, Western knowledge as utility' [zhong xue wei ti, xi xue wei yong, 中學為體,西 學為用]. See Ssu-yu Teng and John King Fairbank (eds), China's Response to the West: A Documentary Survey, 1839-1923, with a New Preface (Cambridge: Harvard University Press, 1979). 
last, given the multiplicities that make world politics, we need to look at the larger context created by and productive of works like Violence and Civilization in the Western States-System: that is, HEW.

\section{V.ii. How? Hypermasculine Eurocentric Whiteness (HEW)}

Linklater's analysis reflects and perpetuates a global infrastructure that I call Hypermasculine Eurocentric Whiteness (HEW). ${ }^{56}$ Hypermasculinity refers to an ideology that denigrates anything smacking of the feminine: for example, welfare, intellection, compassion. ${ }^{57}$ Accordingly, Hypermasculinity needs no partner to come into being. Like a masculinised Athena, Hypermasculinity springs fully-grown from Zeus's Western head. At the same time, Hypermasculinity has a patriarchal persona. Not only can it impregnate Others, as evidenced by the multiple mini-Wests that populate the formerly colonised world, but Hypermasculinity's patriarchal persona also treats all Others as either sexual subordinates (wives/mistresses/prostitutes) or infantilised inferiors (children/servants/ slaves). ${ }^{58}$ Both require 'education' from the Hypermasculine-Patriarch. ${ }^{59}$ (Still, HEW winks, they can never catch up to $u s !)^{60}$ Eurocentrism regards all things European - people, customs, languages, institutions, philosophies, even fashions and lifestyles - as definitive of 'civilisation'. ${ }^{61}$ Eurocentrism ensures that Hypermasculinity represents and promotes the West; otherwise, Other patriarchal traditions could take hold. Like James Bond, the West represents the Best. And whiteness constructs a racialised order of privilege and entitlement that permits a false sense of benevolence, graciously granted to Others but, really, serving the Western Self's own interests. ${ }^{62}$ For this reason, the term 'how white of you' bites even as it smiles.

HEW updates colonial management with seemingly inclusive slogans like a 'liberal world order'. But HEW still preaches universalising singular 'standards' derived from one cultural context (Eurocentrism), one racial identity (whiteness), and one sexual posture (hypermasculinity). In other words, Linklater can make the kind of analysis he does, with the implications it has, and still receive public adulation (this forum as one example) because he conforms to and perpetuates HEW.

${ }^{56}$ L. H. M. Ling, 'Don't flatter yourself: World politics as we know it is changing and so must disciplinary IR', in Synne L. Dyvik, Jan Selby, and Rorden Wilkinson (eds), What Is the Point of IR? (London: Routledge, 2017), pp. $135-46$.

57 This concept comes from Nandy, The Intimate Enemy.

58 With regards to Asia, see Ling, Postcolonial International Relations.

59 See, for example, how Locke reconciles his love of individual liberty with his endorsement of slavery. Joshua Foa Dienstag, 'Serving God and Mammon: the Lockean sympathy in early American thought', American Political Science Review, 90:3 (1996), pp. 497-511.

${ }^{60}$ For one demonstration of how HEW applies this double move in the international political economy, see L. H. M. Ling, 'Cultural chauvinism and the liberal international order: "West versus rest" in Asia's financial crisis', in Geeta Chowdhry and Sheila Nair (eds), Power, Postcolonialism, and International Relations: Reading Race, Gender, Class (London: Routledge, 2002), pp. 115-41.

${ }^{61}$ Gerrit W. Gong, The Standard of 'Civilization' in International Society (Oxford: Clarendon Press, 1984); Anthony Anghie, Imperialism, Sovereignty, and the Making of International Law (Cambridge: Cambridge University Press, 2005); Cemil Aydın, The Politics of Anti-Westernism in Asia: Visions of World Order in Pan-Islamic and Pan-Asian Thought (New York: Columbia University Press, 2007); Brett Bowden, The Empire of Civilization: The Evolution of an Imperial Idea (Chicago: The University of Chicago Press, 2009); Shogo Suzuki, Civilization and Empire: China and Japan's Encounter with European International Society (New York, Routledge, 2009).

62 James Baldwin, 'On Being White ... And Other Lies' (1984), available at: \{http://www.cwsworkshop.org/pdfs/ CARC/Family_Herstories/2_On_Being_White.PDF\} accessed 31 December 2015. 


\section{The house of IR}

Like a good colonial administrator/patriarch, Linklater writes from the cushy study of HEW's main residence, the House of IR. ${ }^{63}$ Built by HEW's worshipped ancestors, Global Capitalism and the White Imperialist State, the House of IR divides into an 'upstairs' for the Family ${ }^{64}$ and a 'downstairs' for Servants and other 'lesser' characters. ${ }^{65}$ Likewise, Linklater exploits the resources of Others outside the House of IR, trafficking in the currency of pain and victimisation, for the Western Self's higher moral development. At the same time, he does not give Others any credit for their contributions nor does he invite them in for tea, not to mention a stay or, heaven forbid, build another house together. Linklater presumes that the status quo benefits everyone in the long run: that is, we keep inside vs outside, upstairs vs downstairs, family vs strangers.

Though tantalising, hegemony ultimately disappoints. In marriage, a partnership in name only quickly dissolves into anger, resentment, deception, and retribution. Similarly, the colonial household could never keep up 'proper' appearances with the parents having all sorts of affairs outside the House (for example, Pater Realism's liaison with Vixen Economics, ${ }^{66}$ Mater Liberalism's with Sexy Critical Theory), ${ }^{67}$ sons and daughters 'going native' (for example, Queer IR), ${ }^{68}$ and métis progeny (for example, Asian capitalism) ${ }^{69}$ knocking on the Family's door. Similarly, Linklater omits the struggles as well as co-productions between the West and the Rest in making 'international society'. Without addressing this fundamental relationship, Linklater inflicts the worst violence of all: non-learning.

We must, in short, transcend. If not, as in the Mahabharata, members of the same family will end up warring against one another. Or, as with Oppenheimer, a lack of substantive interactions with Others would leave us bereft, no matter how many times we read the Gita.

But how?, I beseech the universe. How do we transcend such violence?

Nothing happens. No bolt of lightning, clap of thunder or gust of godly wind. Only 'breaking news' pops up on my phone, now and then. Indeed, all signs today suggest we are heading toward the opposite of transcendence.

\section{Alt-right in contemporary politics}

The current rise of ultra-right wing movements in the US, Europe, Russia, Turkey, and elsewhere simply startles. We know too well what happened to fascism just three generations ago. Yet even

${ }^{63}$ A. M. Agathangelou and L. H. M. Ling, 'The house of IR: From family power politics to the poisies of worldism', International Studies Review, 6:4 (2004), pp. 21-49.

${ }^{64}$ The Family (proper) consists of Pater Realism and Mater Liberalism and their large brood: the heir-apparent (Neo-Realism, albeit from an affair between Pater Realism and Vixen Economics); rebel sons (Marxism, Gramscian IPE, Postmodern IR, Constructivism-Pragmatism); care-taking daughters (Neoliberalism, Liberal Feminism, Standpoint Feminism); alongside their fallen sisters (Postmodern Feminism, Queer Studies); and, of course, all sorts of illegitimate wards like Asian Capitalism.

${ }^{65}$ Servants in the House of IR come in the form of native informants: for example, area studies experts or comparativists.

66 See, for example, Kenneth Waltz, Theory of International Politics (Reading: Addison-Wesley, 1979).

${ }^{67}$ See, for example, Martha Nussbaum, Sex and Social Justice (Oxford: Oxford University Press, 1999).

${ }^{68}$ See, for example, Cynthia Weber, Queer International Relations: Sovereignty, Sexuality and the Will to Knowledge (London: Oxford University Press, 2016).

${ }^{69}$ See, for example, Ling, Postcolonial International Relations. 
core members of the 'liberal world order' now want to retrieve fascist policies, especially to keep out (certain) immigrants ('Brexit', US-Mexico wall, travel ban) but also to contain internal 'troublemakers' such as investigative journalists, dissident academics, and activist minorities. Some on the Left claim that these policies are nothing new. Governments in the industrialised West have always exploited Others. When their economies boomed, they welcomed immigrants as cheap labour. Once the boom ends, so does the national welcome.

What disturbs me more - and this is related to my critique of Linklater - is the lack of learning involved. We all know, for example, that the US started out by treating African slaves as three fifths of a human being. Would a return to that mean the US is simply resuming its historical trajectory? Ronald Reagan as President of the US apologised to Japanese Americans, for the first time in 1988, for interning their elders from $1942-5 .{ }^{70}$ Why does this precedent not serve as a cautionary reminder for current hate crimes against Muslims in America? Why, I ask, is the present not held to account for the hard-won victories of the past?

Certainly, I do not hold Linklater responsible for any of these developments. But I do see how his line of inquiry - which, as this review has shown, hobbles systemic learning from, by, and with Others links with the current political regression into nostalgic fascism. The former does not cause the latter. But Linklater's analytical framework, as an instrument of HEW, reinforces a tendency towards fascism. Or, to put it differently, the House of IR cannot check xenophobia, Islamaphobia, or any Other-directed phobias because it, too, derives from HEW. We need to face this power context honestly if we seek justice, not just morality, in world politics.

The din of recess distracts me. An elementary school flourishes nearby but I never see it. The City, being what it is, has too many buildings blocking the view. Still, I can hear the children whenever they're freed from class for half an hour each day. On this warm spring day, their voices ring especially strong and joyful, loud and boisterous - precisely how children should sound when playing ... PLAY! That's it, I snap my fingers.

\section{The power of play}

'We are still here. ${ }^{71}$ With these four simple words, the Andean activist Humberto Cholango conveys a whole world to Pope Benedict XVI in 2007. In his letter, Cholango explains to the Pope: 'Our religions NEVER DIED [because] we learned how to merge our beliefs and symbols with the ones of the invaders and oppressors. ${ }^{, 72}$ Put differently, the indigenous peoples of the Andes learned how to absorb and adapt, reframe and reformulate even that which seemed 'foreign' or 'alien'. In effect, they applied the lesson of the Bhagavad Gita. Dharmic detachment does not mean a lack of regard for the purpose of detachment: that is, concern for the whole alongside the particular. ${ }^{73}$ The peoples of the Andes put this principle into practice by learning how to play. ${ }^{74}$

${ }^{70}$ George Takei, 'Internment: America's great mistake', New York Times (28 April 2017), available at: \{https:// www.nytimes.com/2017/04/28/opinion/george-takei-japanese-internment-americas-great-mistake.html?_r=0 accessed 28 April 2017.

71 Cholango quoted in Marisol de la Cadena, 'Indigenous cosmopolitics in the Andes: Conceptual reflections beyond “politics", Cultural Anthropology, 25:2 (2010), p. 335.

72 Ibid., p. 334, emphasis in original.

73 One of Krishna's injunctions to Arjuna is to consider what would happen to his family if he did not go to war.

${ }^{74}$ For the importance of play in IR theorising, see L. H. M. Ling, 'Onuf's radical subtlety', in Harry Gould (ed.), The Art of World Making: Nicholas Greenwood Onuf and his Critics (London: Routledge, 2017), pp. 54-65. 
Nick Onuf theorises on the importance of play for world-making. ${ }^{75}$ Playfulness, he observes, provides another way to create worlds: it constitutes a 'third way of living'. ${ }^{76}$ It may be the most important way to create worlds, I add, for playfulness gives us the freedom to engage with Others. All games involve rules but part of the creativity of play is to come up with the rules together. For this reason, play often involves lengthy negotiations, back and forth, and at different pitches of intensity, depending on who's playing what with whom. Nonetheless, curiosity motivates us all and the fun of playfulness invariably leads to inclusion and respect. After all, who can resist the joy of play? ${ }^{77}$

For this reason, I write this review as a personal journey. Rather than resort to the usual academic convention of couched phrases that say little but reveal much, I want to share my honest reactions to what I am reading. Not only is honesty the greatest form of respect, but it is also high time I voice myself to the discipline. But I speak on behalf of myself only, as one member of the Global South who is also deeply entwined with the Global North, as we all are, whether located in the North or the South, whether we care to admit it or not. In this review, I openly record my feelings in an artistic, playful way. My reactions range from outrage to disgust to sadness to ennui. But I also take to heart Sojourner's truth: we redeem ourselves morally and spiritually by, at base, listening to and hearing Others.

Herein may lie our salvation and emancipation. Drawing on Cholango, I say to the beautiful but sad, lonely, confused, and ultimately self-deluded unicornic West:

Stop hiding in that big, old, scary house all by yourself. Come out and play!

I am here. We are here. We may have suffered much at your hands - and continue to feel the pain - but we have triumphed over tragedy. And we have done so joyously, mirthfully. Just look at how we eat! ${ }^{78}$ But do not mistake our resilience for a child-like innocence. We know fully well what you have done and what you continue to do. For this reason, some may wish to do onto you what you have done onto them. But we don't want to play that game. It's not fun. Instead, we want to explore and experiment, create and conjure, imagine and colour, ${ }^{79}$ hop-skip-and-jump!

Come, join us! Let's play. ${ }^{80}$

\section{Acknowledgements}

I thank Payal Banerjee, Sneha George, Juliana Mendes de sa Beckert, Nicholas G. Onuf, Shirin M. Rai, V. Spike Peterson, Patricia J. Robertson, and Sara Shroff for their comments on this article. Of course, the author retains any responsibility for errors or confusions within. Many thanks, also, to John M. Hobson for inviting me to participate in this review.

75 Onuf, Making Sense, Making Worlds.

76 Winnicott cited in Ibid., p. 90.

77 See, for example, L. H. M. Ling, 'On relations and relationality: Conversations with an old friend', paper delivered at the workshop, 'Futures of Global Relations', University of Lancaster, 16-17 May 2017.

${ }^{78}$ See, for example, Rachel Laudan, Cuisine \& Empire: Cooking in World History (Berkeley: University of California Press, 2013).

${ }^{79}$ L. H. M. Ling, 'World politics in colour', Millennium: Journal of International Studies, 45:3 (2017), pp. 1-19.

${ }^{80}$ For an example of 'play' in IR, in all its senses, see L. H. M. Ling, 'Wanda's dream: Daoist world politics in five acts', in Olivia Rutazibwa and Robbie Shilliam (eds), Routledge Handbook of Postcolonial Politics (London: Routledge, forthcoming). 


\section{Biographical information}

L. H. M. Ling is Professor of International Affairs at The New School in New York. Her research focuses on a post-Western, post-Westphalian approach to world politics called Worldism: that is, we live in a world of multiple worlds. She is the author of four books: Postcolonial International Relations: Conquest and Desire between Asia and the West (2002); Transforming World Politics: From Empire to Multiple Worlds (co-authored with A. M. Agathangelou, York University, 2009); The Dao of World Politics: Towards a Post-Westphalian, Worldist International Relations (2014); and Imagining World Politics: Sihar \& Shenya, A Fable for Our Times (2014). Two books are forthcoming: A Worldly World Order: Epistemic Compassion for International Relations (Oxford University Press) and Between India and China: An Ancient Dialectic for Contemporary World Politics (co-authored with Payal Banerjee, Smith College, Rowman \& Littlefield). Professor Ling has edited or co-edited the following anthologies: Asia in International Relations: Unlearning Imperial Power Relations (co-edited with Pinar Bilgin, 2017); India China: Rethinking Borders and Security (2016); and Four Seas to One Family: Overseas Chinese and the Chinese Dream (co-edited with Tan Chung, in Chinese and English, 2015). Along with John M. Hobson (Sheffield University), Professor Ling co-edits a book series, Global Dialogues: Developing Non-Eurocentric International Relations and International Political Economy, at Rowman \& Littlefield International. Professor Ling was Associate Dean of Faculty Affairs, Schools of Public Engagement (SPE) at The New School from 2012-15. 